\title{
Phytoprotection
}

\section{A note on the detection of bean yellow mosaic virus infecting white lupine in Canada}

\section{Piché, J. Peterson et M.G. Fortin}

Volume 74, numéro 3, 1993

URI : https://id.erudit.org/iderudit/706044ar

DOI : https://doi.org/10.7202/706044ar

Aller au sommaire du numéro

Éditeur(s)

Société de protection des plantes du Québec (SPPQ)l

ISSN

0031-9511 (imprimé)

1710-1603 (numérique)

Découvrir la revue

Citer cet article

Piché, C., Peterson, J. \& Fortin, M. (1993). A note on the detection of bean yellow mosaic virus infecting white lupine in Canada. Phytoprotection, 74(3), 153-155. https://doi.org/10.7202/706044ar
Résumé de l'article

Des symptômes de mosaïque virale ont été observés dans des champs expérimentaux de lupin (Lupinus albus) dans Test du Canada. Les plants affectés montraient des symptômes de mosaïque, de réduction et de déformation des feuilles, et de nanisme du plant. Les symptômes ont pu être reproduits en serre par inoculation mécanique sur le cultivar de lupin Ultra. Les symptômes observés sur des espèces diagnostiques, l'observation par microscopie électronique, la détection sérologique ELISA et l'analyse immunologique Western ont été utilisés pour identifier le virus présent. Un potyvirus, identifié comme le virus de la mosaïque jaune du haricot (BYMV), a été détecté dans les plants affectés. Ces résultats sont les premiers à caractériser une maladie virale du lupin au Canada. Puisque le virus est transmis par les pucerons et par la graine, la présence du virus peut devenir une limitation à la production du lupin. 


\title{
A note on the detection of bean yellow mosaic virus infecting white lupine in Canada
}

\author{
Christian Piché 1 , Jean Peterson"1, and Marc G. Fortin ${ }^{1}$
}

Received 1992-06-18; accepted 1993-08-24

Virus-like symptoms were observed in fields of white lupine (Lupinus albus) in Eastern Canada. Affected plants displayed mosaic, leaf stunting and deformation, and bunchy growth habit. The disease was successfully reproduced in greenhouse by mechanical inoculation of white lupine cv. Ultra. The causal virus was identified as bean yellow mosaic virus (BYMV) by symptomatology on diagnostic species, electron microscopy, enzyme linked immunosorbent assay (ELISA) and immunodetection after Western blotting. This is the first report of a viral disease of lupine in Canada. BYMV may represent a significant limitation to lupine culture since it is transmitted by aphids and through infected seed.

Piché, C., J. Peterson et M. G. Fortin. 1993. Une note sur la détection du virus de la mosaïque jaune du haricot infectant le lupin blanc au Canada. PHYTOPROTECTION 74: 153-155.

Des symptômes de mosaïque virale ont été observés dans des champs expérimentaux de lupin (Lupinus albus) dans l'est du Canada. Les plants affectés montraient des symptômes de mosaïque, de réduction et de déformation des feuilles, et de nanisme du plant. Les symptômes ont pu être reproduits en serre par inoculation mécanique sur le cultivar de lupin Ultra. Les symptômes observés sur des espèces diagnostiques, l'observation par microscopie électronique, la détection sérologique ELISA et l'analyse immunologique Western ont été utilisés pour identifier le virus présent. Un potyvirus, identifié comme le virus de la mosaïque jaune du haricot (BYMV), a été détecté dans les plants affectés. Ces résultats sont les premiers à caractériser une maladie virale du lupin au Canada. Puisque le virus est transmis par les pucerons et par la graine, la présence du virus peut devenir une limitation à la production du lupin.

Lupine (Lupinus albus L.) is an alternative to soybean for the production of a high protein crop in temperate climates. It is more tolerant of low soil $\mathrm{pH}$ and low temperatures than soybean, two limiting factors for soybean production in northeastern North America. Seventeen virus and mycoplasma-like diseases have been reported to infect lupine, but two virus diseases are more prevalent: bean

1. Department of Plant Science, Macdonald Campus of McGill University, 21111 Lakeshore Road, Sainte-Anne-de-Bellevue, Québec, Canada H9X 3V9 yellow mosaic virus (BYMV) and cucumber mosaic virus (CMV) (Jones and McLean 1989). Plants in experimental fields of white lupine established in eastern Canada displayed virus-like symptoms ressembling those reported for BYMV. BYMV, a member of the potyvirus family, is transmitted to lupine plants by aphids and through seed. BYMV has a wide host range that includes most leguminous plants (Bos 1970). Infected white lupine plants display narrower leaflets, vein clearing, necrotic spotting, severe mosaic and leaf deformation. Early infection results in severe stunting and bushy appearance of 
plants (Jones and McLean 1989). We report here the successful propagation of the disease under greenhouse conditions, and the detection of BYMV in infected white lupine. This is the first report of a viral disease of white lupine in Canada.

Ninety-eight accessions of white lupine were grown in experimental plots at the Macdonald Campus of McGill University near Montréal, Québec. Symptoms displayed by affected plants in the field included reduced leaf size, mosaic, occasional necrotic spotting of the stem, leaf mottling, and a characteristic stunting of leaves on younger branches that gave plants a bushy appearance. Some cultivars (cvs. Primorski and Ultra) seemed more affected than others. Resistance or tolerance to viruses in white lupine has not been reported. The number of leaves affected by this stunting ranged from a few upper leaves to most leaves on the plant. Leaves of plants showing viruslike symptoms were collected and frozen at $-70^{\circ} \mathrm{C}$. In order to reproduce symptoms observed in the field under greenhouse conditions, white lupine cv. Ultra was inoculated with frozen infected leaves ground in $0.1 \mathrm{M}$ potassium phosphate at $\mathrm{pH}$ 7.0. Symptoms observed were identical to those observed in the field and matched those described by Jones and McLean (1989) for BYMV infection on white lupine. We observed necrotic spotting of the stem, but it was not followed by death of the plant.

Four diagnostic species were inoculated: Chenopodium amaranticolor Coste \& Reyn, Cucumis sativus L. cv. Chicago Pickling, Nicotiana tabacum L. cv. White Burley, and Phaseolus vulgaris L. cv. Sprite. Chenopodium amaranticolor and $P$. vulgaris were infected systemically when inoculated with infected leaf sap extract. The systemic infection, necrotic lesions and leaf deformation observed on inoculated (but not mock-inoculated) C. amaranticolor are typical of infection by BYMV (Bos 1970). A severe mosaic was ob-served on $P$. vulgaris also characteristic of BYMV infections (Bos 1970). No symptoms were observed on $C$. sativus and $N$. tabacum when inoculated with the same sap extract. Distinct mosaic on leaves of those two diagnostic species should be observed when infected with CMV (Francki et al. 1979). Symptomatology thus suggests the presence of BYMV and the absence of CMIV in infected leaf extracts.

Electron microscopy was performed on extracts of frozen leaves collected from the field, and on leaf extracts of cultivar Ultra inoculated in the greenhouse. Long filamentous rod particles averaged $710 \mathrm{~nm}$ in length and these measurements are in agreement with the range of viral particle length for potyviruses $(680 \mathrm{~nm}$ to $900 \mathrm{~nm}$; Matthews 1979). The average particle length for BYMV is $750 \mathrm{~nm}$ (Moghal and Francki 1981). No spherical particles characteristic of CMV were observed.

In ELISA assays, the anti-potyvirus serum (Agdia Inc., Elkhart, IL) bound to infected plant extracts from both field and greenhouse samples, but not to uninfected leaf material. Infected leaves generated ELISA readings approximately 100 fold higher than control samples (either mock-inoculated or uninoculated). However, the Agdia potyvirus antiserum used for the ELISA tests cannot distinguish between various potyviruses. To clearly establish that BYMV was present in the infected samples, an antiserum raised against partially purified EYMV (Drs. R.I. Hamilton and R. Stace-Smith, Agriculture Canada, Vancouver) was used to detect the presence of BYMV capsid protein on Western blots of SDS-PAGE separated leaf extracts. For Western blotting, leaf extracts were electrophoresed in a $12.5 \%$ denaturing polyacrylamide gel according to Hames and Rickwood (1981).

Detection of antigen-antibody complexes was performed using goat antirabbit IgGs linked to alkaline phosphatase (Bio-Rad). The antibodies detected a band of the expected size for the coat protein of BYMV, which has been reported to be $30.9 \mathrm{kD}$ by Hammond and Hammond (1989). No CMV was detected by ELISA in sap extracts prepared from field samples. We verified that the absence of reaction was not due to a failure of the antiserum to recognize CMV. Tobacco leaves infected with CMV (PV-29 from American Type Culture Collection) produced a strong reaction when used in the 
same assay. A new potyvirus infecting white lupine was recently characterized by Hampton et al. (1992). White lupine mosaic virus (WLMV) is closely related to, but distinct from BYMV in host range, serology and coat protein peptide map profiles. WLMV did not infect $C$. amaranticolor and $P$. vulgaris (Hampton et al. 1992), whereas BYMV and the virus present in our samples did infect these species. Four potyviruses other than BYMV are known to infect white lupine (Jones and McLean 1989): clover yellow vein virus (CYVV), bean common mosaic virus (BCMV), peanut mottle virus (PMV), and bidens mottle virus (BiMV). CYVV, BiMV and PMV are not likely candidates for the potyvirus found in our samples since they do not cause systemic infections when inoculated on $C$. amaranticolor (Demski et al. 1983; Hollings and Stone 1974), as observed with BYMV. BCMV causes only faint local lesions on C. amaranticolor (Bos 1971), again not in agreement with the symptoms we observed upon inoculation using infected leaf extracts. In addition, Frencel and Pospieszny (1979) found that mechanical inoculation of BCMV on $L$. albus cv. Kali did not produce symptoms, whereas we were able to routinely obtain symptoms using infected field samples.

We have determined that the symptoms observed in fields of white lupine in Canada were caused by BYMV. The virus was identified by symptoms produced on diagnostic species, by electron microscopy, and with an antiserum prepared against BYMV. The disease could be propagated mechanically under controlled environment conditions. Since most plants in plots of some cultivars were infected and severely stunted, BYMV may represent an important limitation to lupine production.

\section{ACKNOWLEDGEMENTS}

We wish to thank Drs. M. Faluyi, D.L. Smith and D.E. Mather for their assistance with lupine plants. We are indebted to Dr. R.I. Hamilton and R. Stace-Smith
(Agriculture Canada, Vancouver) for the generous gift of BYMV antiserum. This research was supported by a grant to Marc G. Fortin from the Natural Sciences and Engineering Research Council of Canada.

\section{REFERENCES}

Bos, L. 1970. Bean yellow mosaic virus. Description of plant viruses. No. 40. Commonw. Mycol. Inst./Assoc. Appl. Biol., $4 \mathrm{pp}$.

Bos, L. 1971. Bean common mosaic virus. Description of plant viruses. No. 73. Commonw. Mycol. Inst./Assoc. Appl. Biol., $4 \mathrm{pp}$.

Demski, J.W., H.D. Wells, J.D. Miller, and M.A. Khan. 1983. Peanut mottle virus epidemics in lupines. Plant Dis. 67: 166-168.

Francki, R.I.B., D.W. Mossop, and T. Hatta. 1979. Cucumber mosaic virus. Description of plant viruses. No. 213. Commonw. Mycol. Inst./Assoc. Appl. Biol., 6 pp.

Frencel, I., and H. Pospieszny. 1979. Viruses in natural infections of yellow lupin (Lupinus luteus L.) in Poland. IV. Bean common mosaic virus (BCMV). Acta Phytopathol. Acad. Sci. Hung. 14: 279-284.

Hames, B.D., and D. Rickwood. 1981. Gel electrophoresis of proteins. IRL Press, Washington. $383 \mathrm{pp}$.

Hammond, J., and R.W. Hammond. 1989. Molecular cloning, sequencing and expression in Escherichia coli of the Bean Yellow Mosaic Virus coat protein gene. J. Gen. Virol. 70: 1961-1974.

Hampton, R.O., D.D. Shukla, and R.L. Jordan. 1992. Comparative potyvirus host range, serology, and coat protein peptide profiles of White Lupin Mosaic Virus. Phytopathology 82: 566-571.

Hollings, M., and O.M. Stone. 1974. Clover yellow vein virus. Description of plant viruses. No. 131. Commonw. Mycol. Inst./ Assoc. Appl. Biol., 4 pp.

Jones, R.A.C., and G.D. McLean. 1989. Virus diseases of lupin. Ann. Appl. Biol. 114: 609-637.

Matthews, R.E.R. 1979. Classification and nomenclature of viruses. Third report of the International Committee on Taxonomy of Viruses. Intervirology 2: 132-296.

Moghal, S.M., and R.I.B. Francki. 1981. Towards a system for the identification and classification of potyviruses. Virology 112 : 210-216. 